\title{
Aspects of the Regulation of Adenylate Cyclase Synthesis in Escherichia coli K12
}

\author{
By A. ROY $\dagger$ P. GLASER AND A. DANCHIN* \\ Institut Pasteur, Département de Biochimie et Génétique Moléculaire, 28 Rue du Dr Roux, \\ 75724 Paris Cedex, France
}

(Received 26 June 1987; revised 25 September 1987)

\begin{abstract}
In Escherichia coli $\mathrm{K} 12$ expression of the adenylate cyclase gene is subject to multiple controls. In order to gain understanding of the regulation of adenylate cyclase synthesis, operon and protein fusions were constructed by in vitro recombination either into bacteriophage $\lambda$ or low-copynumber plasmids, or directly on the chromosome at the cya locus. The fusions were used in physiological experiments as probes to study transcriptional and translational controls of cya expression. It was found that adenylate cyclase synthesis was insensitive to glucose effects. As already described by other workers, the $\mathrm{CAP}-\mathrm{cAMP}$ complex had a moderate negative control on cya expression. In addition it was observed that concomitant with a severe slackening of growth rate, specific to the growth of cya strains in rich medium, cya expression was considerably enhanced. This increase of adenylate cyclase synthesis did not appear to be directly dependent on the presence of a functional cAMP receptor (CAP), and seemed to be controlled at the level of transcription. Finally, translation of the cya message was very weak when compared to cya transcription (the mRNA level was the same in protein and operon fusions).
\end{abstract}

\section{INTRODUCTION}

In bacteria, adenosine $3^{\prime}: 5^{\prime}$-cyclic monophosphate (cAMP) controls the synthesis of many enzymes and various membrane-associated proteins (Botsford, 1981; Ullmann \& Danchin, 1983). Such control depends on the nature of the carbon source and requires the presence of a functional cAMP receptor protein, CAP (Botsford, 1975; Epstein et al., 1975; Wayne \& Rosen, 1974). In Escherichia coli, cAMP is also involved as a modulator of catabolite repression: low cAMP levels are correlated with a severe reduction in the synthesis of enzymes involved in carbon catabolism. In addition, the cAMP-CAP complex is involved in transcription termination of several polycistronic operons (Ullmann et al., 1979; Guidi-Rontani et al., 1984). However, whereas the molecular mode of action of the cAMP-CAP complex seems relatively well understood (De Crombrugghe et al., 1984), the processes controlling variations of intracellular cAMP levels remain unclear. In fact, it has been shown that cAMP is very efficiently excreted from the cell (Matin \& Matin, 1982), and that phosphodiesterase is poorly active in $E$. coli $\mathrm{K} 12$. It has also been shown that $c r p$ strains overproduce cAMP (Potter et al., 1974; Wayne \& Rosen, 1974). This led Botsford \& Drexler (1978) to postulate that CAP in its active conformation (i.e. bound to cAMP) might act as a repressor of the adenylate cyclase gene, cya. Experimental evidence has recently been accumulated which substantiates the latter hypothesis (Aiba, 1985; Kawamukai et al., 1985). However, the actual repression of cya

† Present address: Institut de Biologie Moléculaire et Cellulaire, 15 rue René Descartes, 67084 Strasbourg Cedex, France.

Abbreviations: CAP, cAMP receptor protein; ONPG, $\sigma$-nitrophenyl $\beta$-D-galactoside; X-gal, 5-bromo-4-chloro3-indolyl $\beta$-D-galactoside. 
transcription by cAMP has been found to be weak (two- to sixfold); thus it would hardly explain the large effects observed in vivo (30- to 100-fold increase in crp strains) (Joseph et al., 1982). To elucidate the control of cAMP synthesis, it appeared necessary to investigate the details of cya expression. The cya genes of E. coli (Roy \& Danchin, 1982; Aiba et al., 1983, 1984) and of Salmonella typhimurium (Wang et al., 1981) have been cloned and characterized, and cya gene expression has been studied. In particular, cya-lac $Z$ fusions on multicopy plasmids were constructed, and preliminary physiological results questioned the usual interpretations of the glucose and cAMP-CAP controls of cya expression (Roy et al., 1983b). In the present paper we document a physiological analysis of the expression of cya-lac $Z$ operon and protein fusions in different $E$. coli backgrounds, when present as single copies relative to the chromosome copy number. The fusions were introduced either as bacteriophage $\lambda$ prophage, as low-copy-number plasmids, or directly within the chromosome, and then used as probes to study the transcriptional and translational regulation of cya expression.

\section{METHODS}

Bacterial and phage strains, and growth media. The bacterial and bacteriophage strains used are listed in Table 1 . The usual growth media were the rich medium LB (Miller, 1972), the minimal medium M68 (Ullmann et al., 1976) or the synthetic medium MM1: $\mathrm{NaCl} 100 \mathrm{mM},\left(\mathrm{NH}_{4}\right)_{2} \mathrm{SO}_{4} 10 \mathrm{mM}, \mathrm{MgSO}_{4} \cdot 7 \mathrm{H}_{2} \mathrm{O} 5 \mathrm{mM}, \mathrm{CaCl}_{2} \cdot 2 \mathrm{H}_{2} \mathrm{O} 1 \mathrm{mM}$, $\mathrm{KH}_{2} \mathrm{PO}_{4} 8 \mathrm{mM}, \mathrm{K}_{2} \mathrm{HPO}_{4} 16 \mathrm{~mm}, \mathrm{FeSO}_{4} .7 \mathrm{H}_{2} \mathrm{O} 10 \mu \mathrm{M}, \mathrm{ZnSO}_{4} .7 \mathrm{H}_{2} \mathrm{O} 1 \mu \mathrm{M}, \mathrm{CuSO}_{4} .5 \mathrm{H}_{2} \mathrm{O} 0.1 \mu \mathrm{M}$, $\mathrm{Na}_{2} \mathrm{MoO}_{4} .2 \mathrm{H}_{2} \mathrm{O} 0.1 \mu \mathrm{M}, \mathrm{CoCl}_{2} .6 \mathrm{H}_{2} \mathrm{O} 0.1 \mu \mathrm{M}, \mathrm{MnSO}_{4} .5 \mathrm{H}_{2} \mathrm{O} 0.1 \mu \mathrm{M}, \mathrm{CrCl}_{3} 0.1 \mu \mathrm{M}, \mathrm{NiCl}_{2} 0.1 \mu \mathrm{M}$, supplemented with $0.4 \%$ carbon source (glucose or glycerol), $5 \mu \mathrm{g}$ thiamin $\mathrm{ml}^{-1}$ and $0.1 \%$ Casamino acids. When included, 5bromo-4-chloro-3-indolyl $\beta$-D-galactoside (X-gal) was added at $40 \mu \mathrm{g} \mathrm{ml}^{-1}$, and cAMP at $3 \mathrm{mM}$. R medium was as in Miller (1972); RMM is R medium with addition of $5 \mathrm{mM}-\mathrm{MgSO}_{4}$ and $0.2 \%$ maltose.

Construction of $\lambda$ recombinants carrying cya-lac $Z$ fusions. $\lambda$ recombinants were constructed in vitro. In the case of operon fusions the respective EcoRI DNA fragments of the different cya-lac fusions (Fig. 1) carried by pBR322 derivatives were introduced into bacteriophage $\lambda$ gt 4 DNA digested with $E c o R I$. In the case of the protein fusions, the $E c o$ RI-SacI fragment of each protein fusion plasmid was ligated with the right arm of $\lambda$ gt 4 digested with $E c o$ RI and the left arm of $\lambda$ sew digested with SacI. $\lambda$ recombinant DNA was subsequently packaged in vitro (Hohn, 1979). Lysogeny with phages carrying the cya-lac $Z$ fusions was performed by infecting bacteria at an m.o.i. of $0 \cdot 1$ (in order to obtain preferentially monolysogens), preadsorbing for $10 \mathrm{~min}$ at $30^{\circ} \mathrm{C}$ and plating directly on RMM/X-gal plates containing cAMP in the presence of the $\lambda$ clear phages W30 $(\lambda)$ and W248 $(\lambda \mathrm{h} 80)$. In the case of $c r p$ strains, which lack $\lambda$ receptor, lysogeny was performed by phenotypic mixing of phages carrying the fusions, with $\lambda \mathrm{W} 248$ (h80) (the h80 host receptor synthesis is insensitive to the absence of an active cAMP-CAP complex). For each experiment five to ten lysogens were purified and tested for $\beta$-galactosidase activity. The lowest value was taken as that of a monolysogen.

Construction of low-copy-number plasmids carrying cya-lacZ fusions. For rapid screening of recombinants, smallscale plasmid (Birnboim \& Doly, 1979) and phage (Davis et al., 1980) DNA preparations were employed. Large quantities of plasmid DNA were obtained as previously described (Roy \& Danchin, 1982). In order to introduce

Table 1. Bacterial and bacteriophage strains

Strain Genotype

Source

Bacteria

TP2100

TP2006

TP2339

TP 2065

XA102

XA103

Bacteriophages

$\lambda$ gt4

$\lambda$ sew

$\lambda 1872$ or

1873 or 1873

$\lambda 1865$

$\lambda 1861$
$\mathrm{F}^{-}$xyl lac $\Delta X 74$

$\mathrm{F}^{-}$xyl cya $\Delta$ lac $\Delta X 74 \mathrm{glp}^{*}$

$\mathrm{F}^{-}$xyl cya $\Delta$ crp $\Delta 39$ lac $\Delta X 74 \arg H 1$

$\mathrm{F}^{-} x y l \Phi(c y a-l a c)$ lac $\Delta X 74$ arg $H I$

$\mathrm{F}^{-}$(lac-pro) $\Delta$ nalA rpoB metB argEam supE ara

$\mathrm{F}^{-}$(lac-pro) $\Delta$ nalA rpoB metB argEam supF ara

c 1857 nin5

cI857 nin5 Wam403 Eaml100 Sam100

cI857 nin5 $\Phi\left(\right.$ cya $\left.-l_{a c}^{+}\right)$

cI857 nin5 Wam403 Eaml100 $\Phi\left(\right.$ cya-lac $\left.{ }^{+}\right)$

c1857 nin5 Wam403 Eam1100 $\Phi\left(\right.$ cya $^{+}-$lac $\left.^{+}\right)$
Roy \& Danchin (1982)

Roy \& Danchin (1982)

Roy et al. $(1983 b)$

This study

Coulondre \& Miller (1977)

Coulondre \& Miller (1977)

Davis et al. (1980)

Enquist et al. (1976)

This work, Figure 1

This work, Figure 1

This work, Figure 1

$g l p^{*}$ is a mutation located very near the $\arg H$ gene; it allows growth of a $c y a$ strain with glycerol as carbon source. 
the cya-lacZ fusions into the low-copy-number plasmid pDIA13 (a broad-host-range plasmid belonging to the IncW incompatibility group: De Reuse et al., 1986), the EcoRI-Sall DNA fragment of each multicopy plasmid (Fig. 1) was digested and ligated with pDIA13 digested with the same restriction enzymes. Transformation was performed as previously described (Roy \& Danchin, 1982) and transformants were selected on MacConkey agar plates containing $1 \%(\mathrm{w} / \mathrm{v})$ lactose and kanamycin $\left(25 \mu \mathrm{g} \mathrm{ml}^{-1}\right)$ as required.

Introduction of a cya-lacZ fusion into the E. coli chromosome. The short protein fusion (86 amino acids of adenylate cyclase) was introduced into the chromosome in place of the cya gene as follows. Plasmid pDIA1780 (see Fig. 2), containing a $7 \mathrm{~kb}$ fragment carrying the $c y a$-lacZ protein fusion followed by the end of the putative $c y a X$ gene, was used as a starting material. After restriction with $E c o R I$, the fragment devoid of a replication origin, carrying an intact tetracycline-resistance gene and the $c y a-l a c Z$ fusion, was purified and ligated. It was then used to transform strain TP2100, and tetracycline-resistant clones, having integrated the circularized fragment by homologous recombination, were selected on LB plates containing X-gal $\left(40 \mu \mathrm{g} \mathrm{ml}^{-1}\right)$ and tetracycline $\left(7 \mu \mathrm{g} \mathrm{ml}^{-1}\right)$. The next step was selection for $\mathrm{Cya}^{-}$recombinants using a virulent $\lambda$ phage as selective agent. Such clones were obtained at a frequency of $10^{-3}$, consistent with the expected frequency for homologous recombination (spontaneous resistance to $\lambda$ vir occurs at a frequency lower than $10^{-6}$ ). As expected, all recombinants had lost the tetracycline-resistance gene and were sensitive to the antibiotic. The resulting strain carried a cya-lac $Z$ fusion in place of the wild-type cya gene. In addition the $5^{\prime}$ end of the putative cyaX gene was deleted.

$\beta$-Galactosidase assays. $\beta$-Galactosidase activity was determined by the method of Pardee et al. (1959). One unit (U) of $\beta$-galactosidase was defined as the amount of enzyme that hydrolysed $1 \mathrm{nmol} \mathrm{ONPG} \min ^{-1}$ at $28^{\circ} \mathrm{C}$. Strains characterized phenotypically were grown in the appropriate minimal medium for at least eight generations. Each experimental point shown represents the average of activities determined in three or more independent cultures. Samples from cultures were subsequently streaked on glucose/X-gal plates in order to confirm that spontaneous curing of $\lambda$ or plasmid cya-lac fusions was negligible.

RNA-DNA hybridization. Cells carrying cya-lacZ recombinant bacteriophages were grown at $30^{\circ} \mathrm{C}$ in medium M68 containing $0.4 \%$ glucose and $0.2 \%$ Casamino acids, in the absence or presence of $3 \mathrm{mM}$-cAMP. The cells were pulse-labelled for $2 \mathrm{~min}$ with $\left[5,6^{-3} \mathrm{H}\right]$ uridine $\left[1 \mathrm{mCi} \mathrm{ml}^{-1}, 46 \mathrm{Ci} \mathrm{mmol}^{-1}\left(1.7 \mathrm{TBq} \mathrm{mmol}^{-1}\right)\right]$ and RNA was extracted as described by Hagen \& Young (1978). The yield was of the order of $5 \times 10^{7}$ c.p.m. per mg RNA and was independent of the presence of cAMP in the growth medium.

Plasmid pDIA9001 carrying the lacZ gene (Guidi-Rontani et al., 1984) was digested by EcoRI and denatured with alkali. The DNA was bound to filters according to Gillepsie \& Spiegelman (1965) (nitrocellulose filters, Schleicher and Schuell, no. BA85, 0.45 $\mu \mathrm{m}$ pore size). Microfilters of $6 \mathrm{~mm}$ diameter carrying 1-15 $\mu \mathrm{g}$ plasmid DNA were prepared for each experiment. Filter hybridizations were performed as described by Kourilsky et al. (1974). RNA hybridization in the presence of excess DNA directly determines the total number of counts in the sample, corresponding to maximum level of RNA which can hybridize to the probe.

Reagents. Restriction enzymes, T4 DNA ligase and cAMP were obtained from Boehringer Mannheim, pancreatic T1 RNAase, lysozyme, tetracycline, kanamycin and ampicillin from Sigma, ONPG and X-gal from Serva, $\left[5,6-{ }^{3} \mathrm{H}\right]$ uridine from Amersham and phenol from Carlo Erba.

\section{RESULTS AND DISCUSSION}

\section{Expression of cya-lac fusions in minimal medium: low translation efficiency of the cya message}

Fig. 1 shows the organization of the cya gene, which comprises a long open reading frame (2544 bp), following two promoter regions, P1 and P2 (Roy et al., 1983; Aiba et al., 1984; Aiba, 1985). In order to avoid fluctuations in the plasmid copy number, known to occur with ColE1 derivatives and to interfere with cAMP-mediated controls (Botsford, 1981), the DNA segments containing the $c y a-l a c Z$ fusions were introduced either into bacteriophage $\lambda$ or on plasmids derived from the IncW replicon, as shown in Fig. 1. In addition one of the protein fusions (Fig. 2) was directly introduced into the chromosome in place of the cya gene (strain TP2065).

The effect of extracellular cAMP on $\beta$-galactosidase synthesis was investigated in strains containing the different cya-lac $Z$ fusions. At concentrations $\geqslant 3 \mathrm{mM}$, cAMP had a negative effect, not varying with cAMP concentration, on $\beta$-galactosidase synthesis; a smaller negative effect was detected at $1 \mathrm{mM}-\mathrm{cAMP}$. The strains harbouring the different $\lambda$ recombinants were therefore grown in glucose minimal medium supplemented with $3 \mathrm{mM-cAMP}$, and under such conditions $\beta$-galactosidase synthesis was repressed by a factor of 1.8 for $\lambda 1872,2.4$ for $\lambda 1877$ and 3 for $\lambda 1873$. A similar repression ratio of 3 was found with the protein fusion, $\lambda 1865$. Thus a relatively small negative effect of cAMP was observed on the expression of both operon and protein fusions, more significant when both cya promoter regions were present $(\lambda 1873$ and 


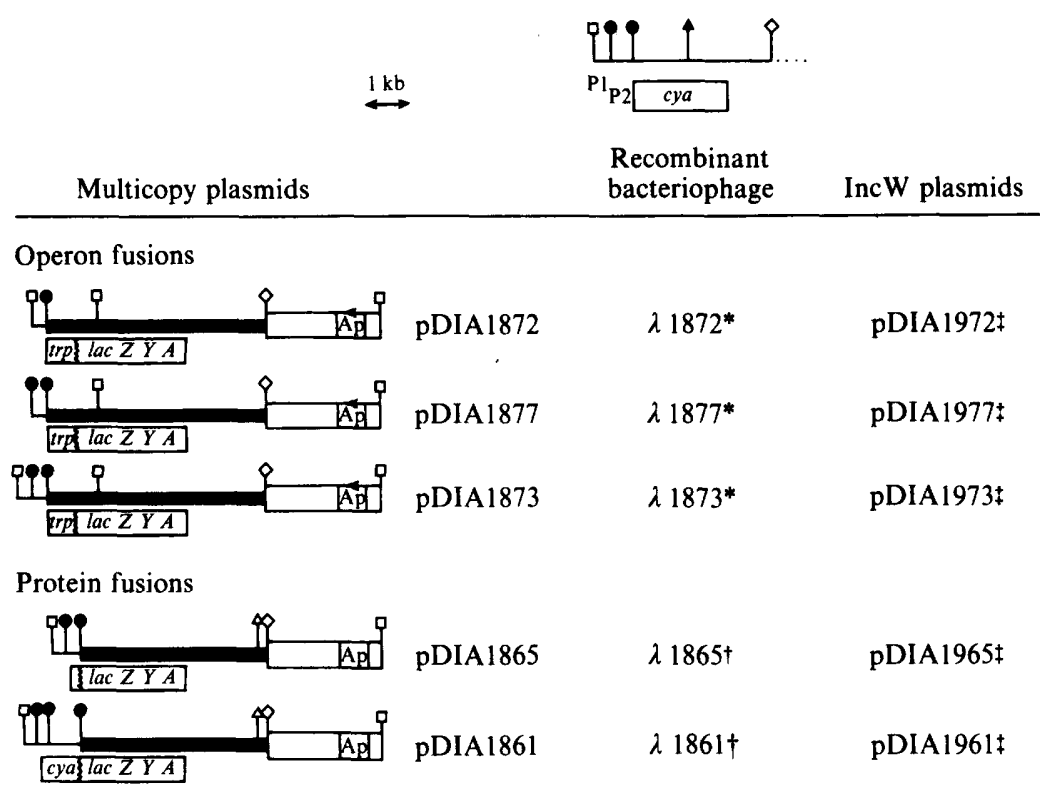

Fig. 1. Restriction map of the $c y a$ gene and $c y a-l a c Z$ fusions. pDIA1872, pDIA1873, pDIA1877 are operon fusions and pDIA1865 and pDIA1861 are protein fusions (Roy et al., 1983b). The heavy line represents the lac operon DNA, the open line DNA from pBR322 and the thin line cya DNA. $\square$,

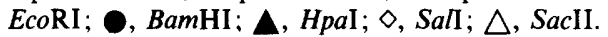

*EcoRI fragment of the respective multicopy plasmids. $\dagger E c o$ RI-SacII fragment of either pDIA1865 or pDIA1861. $\ddagger E c o$ RI-Sall fragment of either operon or protein fusions.

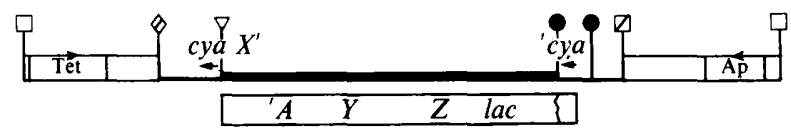

Fig. 2. Restriction map of plasmid pDIA1780. $\nabla$ represents the junction between the $E c o$ RI site at position 3471 in cyaX and the NruI site at position 4980 in lacA. $\nabla$ represents an EcoRI site obtained after ligation of the 'filled in' EcoRI site located upstream from the cya gene with the PvuII site of pBR322. $\checkmark$ represents a $S a l$ site obtained after ligation of the filled Sall site downstream from cya locus with the PvuII site of pBR322. Other symbols are as in Fig. 1.

1865). As can be seen in Table 2 , this effect is mediated by CAP, since $\beta$-galactosidase synthesis did not vary in a crp strain (TP 2339) whether in the presence or in the absence of cAMP. It can also be noticed that cya translation efficiency was very weak when compared to the corresponding transcription level (compare the 1865 construction and the 1873 construction).

The cAMP-mediated negative control, monitored indirectly by measurement of $\beta$ galactosidase activity, was also investigated directly by measuring mRNA synthesis. Total cellular mRNA from strains TP2006 $\lambda 1865$ and TP2006 $\lambda$ 1873, labelled with $\left[{ }^{3} \mathrm{H}\right]$ uridine, was hybridized to increasing concentrations of lac $Z^{\prime}$ DNA (EcoRI restriction fragment from pDIA9001) bound to nitrocellulose filters (Table 3 ). There was a $1 \cdot 5$-fold excess of the operon fusion mRNA synthesized in the presence of cAMP, as compared to the amount synthesized in the absence of the nucleotide. This is quite similar to the ratio observed by measuring $\beta$ galactosidase activities, and in agreement with the results of Aiba (1985) and Kawamukai et al. (1985). The synthesis of mRNA did not vary significantly between the operon fusion and the protein fusion (Table 3 ).

A puzzling observation has to be emphasized here: translation of the cya message seems to be extremely inefficient. Indeed the level of protein fusion expression was decreased more than 
Table 2. Expression of cya-lacZ fusions in the presence and in the absence of cAMP

\begin{tabular}{|c|c|c|c|c|}
\hline \multirow[b]{2}{*}{ Strain } & \multirow[b]{2}{*}{ Bacteriophage } & \multicolumn{2}{|c|}{$\begin{array}{l}\beta \text {-Galactosidase activity } \\
\text { (U per } \mathrm{OD}_{600} \text { unit) }\end{array}$} & \multirow{2}{*}{$\begin{array}{l}\text { Repression } \\
\text { ratio* }\end{array}$} \\
\hline & & No cAMP & $3 \mathrm{mM}-\mathrm{cAMP}$ & \\
\hline \multirow[t]{5}{*}{ TP2006 $\left(c y a, c r p^{+}\right)$} & $\begin{array}{l}\lambda 1872 \\
\text { (operon fusion, } \mathrm{Pl} \text { ) }\end{array}$ & 103 & 54 & $1 \cdot 8$ \\
\hline & $\begin{array}{l}\lambda 1877 \\
\text { (operon fusion, } \mathrm{P} 2 \text { ) }\end{array}$ & 909 & 367 & $2 \cdot 4$ \\
\hline & $\begin{array}{l}\lambda 1873 \\
\text { (operon fusion, P1, P2) }\end{array}$ & 954 & 294 & 3 \\
\hline & $\begin{array}{l}\lambda 1865 \\
\text { (protein fusion, P1, P2) }\end{array}$ & 4 & $1 \cdot 4$ & 3 \\
\hline & $\begin{array}{l}\lambda 1861 \\
\text { (protein fusion, } \mathrm{P} 1, \mathrm{P} 2)\end{array}$ & $1 \cdot 5$ & ND & \\
\hline \multirow[t]{2}{*}{ ТР2339 (cya, crp) } & $\begin{array}{l}\lambda 1873 \\
\text { (operon fusion, } \mathrm{P} 1, \mathrm{P} 2 \text { ) }\end{array}$ & 730 & 730 & 1 \\
\hline & $\begin{array}{l}\lambda 1865 \\
\text { (protein fusion, P1, P2) }\end{array}$ & 4 & 4 & 1 \\
\hline
\end{tabular}

ND, Not determined.

* (Units of $\beta$-galactosidase activity of strains grown in MM1 with glucose as carbon source without cAMP)/(units of $\beta$-galactosidase activity of strains grown in the same medium with 3 mM-cAMP).

Table 3. Synthesis of cya-lacZ-specific $m R N A$ in the absence and in the presence of $c A M P$

Strain TP2006 (cya, lac) harbouring the bacteriophage indicated was grown at $30^{\circ} \mathrm{C}$ in M68 medium supplemented with $0.4 \%$ glucose and $0.2 \%$ Casamino acids in the presence or absence of $3 \mathrm{mM}-\mathrm{cAMP}$, and pulse-labelled for $2 \mathrm{~min}$ with $\left[{ }^{3} \mathrm{H}\right]$ uridine as described in Methods. The respective values given in the columns were obtained from the same RNA preparations using the same amount of TCAprecipitable activity. Non-specific hybridization was determined using RNA from strain TP2006, in which the entire lac operon is deleted.

$\begin{array}{lll}\quad \text { Bacteriophage } & \overbrace{0.001} & \begin{array}{c}\text { Hybridization } \\ \text { (\%o of total input) }\end{array} \\ \text { None } & 0.001 & 0 \cdot 17 \\ \lambda 1873 \text { (operon fusion, P1, P2) } & 0.27 & 0 \cdot 17 \\ \lambda 1865 \text { (protein fusion, P1, P2) } & 0.24 & \end{array}$

100-fold when compared with the level obtained in operon fusions (Table 2 ; see also Table 5). In contrast, the total amount of mRNA measured from operon or protein fusions was similar (Table 3). Both $c y a-l a c Z$ chimaeric proteins displayed the same level of $\beta$-galactosidase activity, suggesting that they had the same turnover number for ONPG. The larger protein has been purified to homogeneity (Danchin et al., 1984), and has been shown to have a turnover number identical to that of wild-type $\beta$-galactosidase and to be cytoplasmic. Thus it can be excluded that the low level of activity was due to some conformational artifact (see Ullmann, 1984). In addition, the chimaeric proteins are stable under different growth conditions (data not shown). The poor expression of $c y a$ therefore seems to be due to a post-transcriptional effect. No special sequence feature (such as palindromes, or a promoter permitting synthesis of anti-mRNA) seems obvious in the case of $c y a$, and so we are left with speculations about the nature of the cya translational control. The only relevant feature in the sequence is that the open reading frame starts with a UUG codon, which is rather rare in Gram-negative bacteria, and which, at least according to Stormo's rule (Stormo et al., 1982), should be a poor initiator. However, several proteins that are expressed at a fairly high level appear to have a UUG start codon (including a ribosomal protein S20: Mackie, 1981). In addition, replacement of UUG by an AUG codon did not drastically affect cya expression (unpublished results; Reddy et al., 1985). Experiments are in progress to clarify this issue. 


\section{Effect of carbon source}

Cellular levels of cAMP are known to fluctuate as a function of the nature of the carbon source on which the strain is grown (Botsford \& Drexler, 1978; Epstein et al., 1975). But Joseph et al. (1982) showed that when bacteria were grown on a variety of carbon sources, adenylate cyclase activity was inversely related to the intracellular concentration of cAMP. In addition it has been observed (Guidi-Rontani et al., 1980; Ullmann \& Danchin, 1983), that catabolite repression can be separated from the cAMP effect, and is a function of the nature of the carbon source (independently of cAMP synthesis). It was therefore of interest to measure the variations of adenylate cyclase synthesis, as a function of the carbon source, using $\beta$-galactosidase as a probe, in the absence of cAMP.

Strain TP2006 harbouring bacteriophage $\lambda$ carrying either operon or protein fusions was grown in minimal medium supplemented either with glucose or with glycerol as carbon source, and $\beta$-galactosidase activity was determined (Table 4 ). This strain was used because, although defective in cyclase activity, and thus unable to grow on a variety of carbon sources such as succinate, it has a mutation in the glycerol operon, allowing growth on glycerol. The highest $\beta$ galactosidase activity was observed when bacteria were exponentially growing on glucose. In the presence of glycerol, slightly lower levels of $\beta$-galactosidase activity were observed when cAMP was absent from the medium, suggesting that adenylate cyclase synthesis is not repressed by glucose. Moreover, no effect of cAMP was observed on expression of either protein or operon fusions, when strains were grown in minimal medium containing glycerol as a carbon source.

\section{Expression of cya-lac fusions in rich medium}

Strains derived from the TP2000 background grow very slowly in minimal medium and are (because of their cya mutation) unable to utilize carbon sources other than glucose (or glycerol in the case of TP2006). Expression of the fusions was therefore studied with bacteria grown in rich medium (at $30^{\circ} \mathrm{C}$ in the case of bacteria harbouring thermosensitive bacteriophage $\lambda$, otherwise at $37^{\circ} \mathrm{C}$ ). A cya-specific effect was observed under such conditions: the cya strain showed an abrupt decrease in growth rate at a density $\left(\mathrm{OD}_{600} 0.9\right)$ far from normal saturation $\left(\mathrm{OD}_{660} 4-5\right)$ when compared with a wild-type counterpart, or when cAMP is added to the growth medium. There was a concomitant increase of $\beta$-galactosidase synthesis (Fig. 3): it increased 5-to 10-fold in each cya-lac $Z$ fusion in the absence of cAMP. Contrariwise, strains grown in the presence of cAMP presented a longer phase of rapid growth and no increase of $\beta$-galactosidase synthesis could be observed (Fig. 3, Table 5). Similar results were obtained when using fusions carried either on $\lambda$ or on low-copy-number plasmids. These observations were specific to cya expression: for instance, no similar increase of $\beta$-galactosidase synthesis could be observed with a fusion between cro and lac $Z$ placed under control of the right $\lambda$ promoter (pDIA3237; De Reuse et al., 1986). Such an increase of adenylate cyclase synthesis was also observed when the protein fusion was integrated at the cya locus on the chromosome (strain TP2065). The increase in $\beta$ galactosidase synthesis was always strictly related to the growth state of the strain (shown by dilution experiments). The reason for the abrupt change in growth rate of cya strains is unexplained. Several parameters were therefore investigated. No significant $\mathrm{pH}$ variations could be observed during growth, and addition of $0.5 \%$ Casamino acids did not restore a longer phase of rapid growth. Starvation for carbon source might be suspected as a cause of this growth rate slackening. Different carbon sources such as glucose, glucose 6-phosphate, fructose, glycerol, pyruvate, sodium acetate and 2-oxoglutarate were therefore tested. These different carbon source supplies delayed, to a greater or lesser extent, the entry into a slow growth phase; as a result of this delay the increase in $\beta$-galactosidase synthesis was abolished (at least in part). Finally, the cAMP and glucose effects were synergistic, as they restored $\beta$-galactosidase synthesis to the level measured during the fast growth phase (Fig. 3).

Thus, in a cya strain grown in rich medium a 5- to 10 -fold increase in $\beta$-galactosidase synthesis, concomitant with a dramatic change in growth rate, was observed. No increase was seen when the rapid growth phase was maintained, either after cAMP addition or after addition of carbon sources such as glucose or glucose 6-phosphate. The effect of cAMP on growth was mediated by CAP, as it was absent in crp mutants; it seems unlikely that it resulted from a direct 

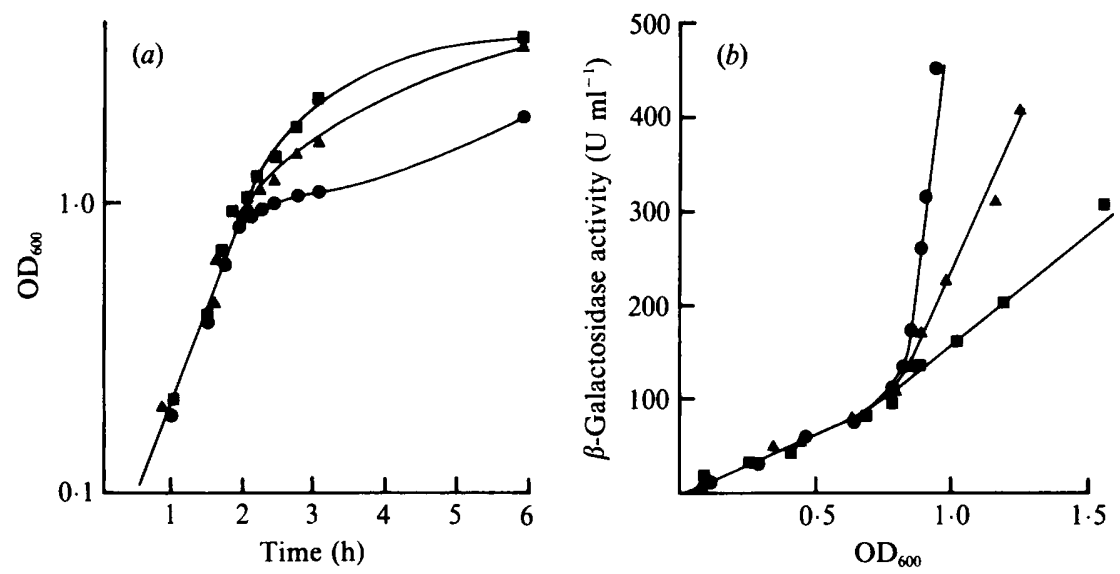

Fig. 3. Growth curve $(a)$ and rate of $\beta$-galactosidase synthesis $(b)$ of strain TP2006 $\lambda 1873$ in rich medium., $\mathrm{LB} ; \boldsymbol{\square}, \mathrm{LB}+\mathrm{cAMP}$ or LB + glucose; $\boldsymbol{A}, \mathrm{LB}+$ fructose.

Table 4. Effect of carbon source on expression of cya-lacZ fusions in strain TP2006 (cya, lac)

$\beta$-Galactosidase activity

$\begin{array}{ccccc}\text { Bacteriophage } & \begin{array}{c}\text { cAMP } \\ (3 \mathrm{mM})\end{array} & \overbrace{\text { Glucose }}^{\text {(U per OD }} & \text { Glycerol } & \begin{array}{c}\text { Repression } \\ \text { ratio* }\end{array} \\ \lambda 1873 & - & 910 & 480 & 1.8 \\ \quad \text { (operon fusion, P1, P2) } & + & 370 & 480 & 0.7 \\ \lambda 1865 & - & 4.2 & 3 & 1.4 \\ \text { (protein fusion, P1, P2) } & + & 1.5 & 1.5 & 1\end{array}$

* (Units of $\beta$-galactosidase activity of strains grown in MM1 with glucose as carbon source)/(units of $\beta$-galactosidase activity of strains grown in MMl with glycerol).

Table 5. Expression of cya-lacZ fusions in rich medium

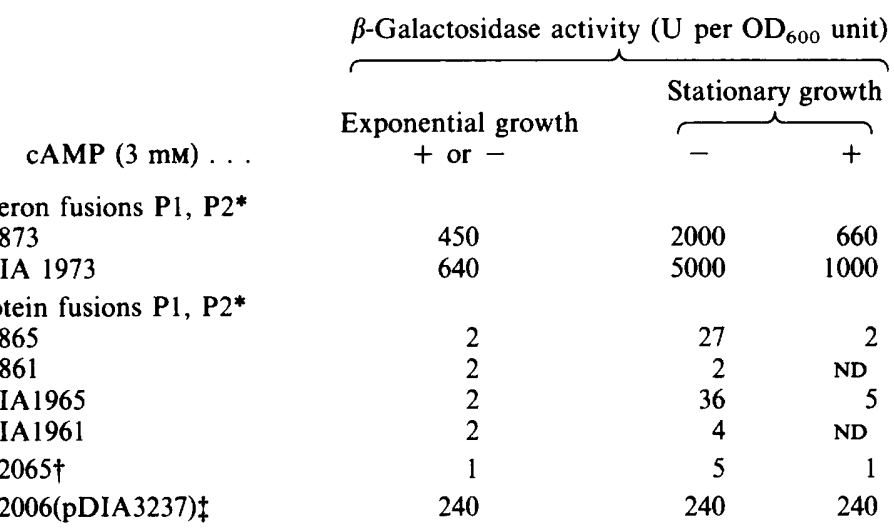

ND, Not determined.

* Operon and protein fusions were in strain TP2006 (cya, lac).

$\uparrow$ TP2065 is the cya-lacZ protein fusion on the chromosome.

$\ddagger$ Plasmid pDIA3237 is a cro-lac $Z$ protein fusion under the control of $\lambda \mathrm{p}_{\mathrm{R}}$. 
action of cAMP, since the same effect was observed with glucose, in the absence of cAMP. The enhancement of adenylate cyclase synthesis observed when cells reduced their growth rate was controlled at the level of transcription (it did not vary between protein and operon fusions). Unfortunately this effect could only be demonstrated when bacteria were grown in a rich medium (LB), and it has not yet been possible to make up a minimal medium where a similar effect can be observed. Indeed in all conditions tested (limitations in carbon or phosphate supply, growth in the absence of oxygen, etc.) cells behaved as if they expressed a partially derepressed cya gene. Further work is therefore needed in order to identify the metabolite(s) responsible for this control of cya expression.

Special thanks are due to H. De Reuse, E. Touati and S. Levy for fruitful discussions. This work benefited from competent advice from M. Springer and C. Guidi-Rontani and expert typing from G. Limeul. Financial support came from CNRS (ATP no. 960094, DVAR no. 899), INSERM (CRE 83 1007) and Institut Pasteur.

\section{REFERENCES}

AlBA, H. (1985). Transcription of the Escherichia coli adenylate cyclase gene is negatively regulated by cAMP-cAMP receptor protein. Journal of Biological Chemistry 5, 3063-3070.

Aiba, H., KawamukaI, M. \& Ishihama, A. (1983). Cloning and promoter analysis of the Escherichia coli adenylate cyclase gene. Nucleic Acids Research 11, 3451-3465.

Aiba, H., MoRI, K., TANAKa, M., ORI, T., ROY, A. \& Danchin, A. (1984). The complete nucleotide sequence of the adenylate cyclase gene of Escherichia coli. Nucleic Acids Research 12, 9427-9439.

Birnboì, H. C. \& Doly, J. (1979). A rapid alkaline extraction procedure for screening recombinant plasmid DNA. Nucleic Acids Research 7, 1513-1523.

BOTSFORD, J. L. (1975). Metabolism of cyclic 3'-5'monophosphate and induction of tryptophanase in Escherichia coli. Journal of Bacteriology 124, 380-390.

Botsford, J. L. (1981). Cyclic nucleotides in procaryotes. Microbiological Review 45, 620-642.

Botsford, J. L. \& DREXLER, M. (1978). The cyclic 3'5 -adenosine monophosphate receptor protein and regulation of cyclic $3^{\prime}-5^{\prime}$-adenosine monophosphate synthesis in Escherichia coli. Molecular and General Genetics 165, 47-65.

Coulondre, C. \& Miller, J. H. (1977). Genetic studies of the lac operon. III. Additional correlation of mutational sites with specific amino acid residues. Journal of Molecular Biology 117, 525-575.

Danchin, A., Guiso, N., Roy, A. \& Ullmann, A. (1984). Identification of the Escherichia coli cya gene product as authentic adenylate cyclase. Journal of Molecular Biology 75, 403-408.

Davis, R. W., Botstein, D, \& Roth, J. R. (1980). A Manual for Genetic Engineering: Advanced Bacterial Genetics. Cold Spring Harbor, NY: Cold Spring Harbor Laboratory.

De Crombrugghe, B., Busby, S. \& Buc, H. (1984). Cyclic AMP receptor protein: role in transcription activation. Science 224, 831-837.

De Reuse, H., Touati, E., Glaser, P. \& Danchin, A. (1986). Low copy number plasmid vectors for gene cloning and for monitoring gene expression. FEMS Microbiology Letters 37, 193-197.

Enquist, L., Tiemer, D., Leder, P., Weisberg, R. \& STEINBERG, N. (1976). Safer derivatives of bacteriophage lambda gt. Lambda $\mathrm{C}$ for use in cloning of recombinant DNA molecules. Nature, London 259 , 596-598.

Epstein, W., Rothman-Denes, L. B. \& Hesse, J. (1975). cAMP as mediator of catabolite repression in Escherichia coli. Proceedings of the National Academy of Sciences of the United States of America 72, 23002304.

Gillepsie, D. \& SPIEgelman, S. (1965). A quantitative assay for DNA-RNA hybrids with DNA immobilized on a membrane. Journal of Molecular Biology 12, 829-842.

Guidi-Rontani, C., Danchin, A. \& Ullmann, A. (1980). Catabolite repression in Escherichia coli mutants lacking cyclic AMP receptor protein. Proceedings of the National Academy of Sciences of the United Siates of America 77, 5799-5801.

Guidi-Rontani, C., Danchin, A. \& Ullmann, A. (1984). Transcriptional control of polarity in Escherichia coli by cAMP. Molecular and General Genetics 195, 96-100.

Hagen, F. S. \& Young, E. T. (1978). Effect of RNAse III on efficiency of translation of bacteriophage T7 lysozyme mRNA. Journal of Virology 26, 793-804.

HoHN, B. (1979). In vitro packaging of $\lambda$ and cosmid DNA. Methods in Enzymology 68, 299-309.

Joseph, E., Bernsley, C., Guiso, N. \& UllmanN, A. (1982). Multiple regulation of the activity of adenylate cyclase in Escherichia coli. Molecular and General Genetics 185, 262-268.

Kawamukai, M., Kishimoto, J., Utsumi, R., Himeno, M., Komano, T. \& AiBa, H. (1985). Negative regulation of adenylate cyclase gene $(c y a)$ expression by cyclic AMP-cyclic AMP receptor protein in Escherichia coli: studies with cya-lac protein and operon fusion plasmids. Journal of Bacteriology 164, 872-877.

Kourilsky, P., Mercereau, O., Gros, D. \& TrembLAY, G. (1974). Hybridization on filters with competitor DNA in the liquid phase in a standard and a micro-assay. Biochimie 56, 1215-1221.

MACKIE, G. A. (1981). Nucleotide sequence of the gene for ribosomal protein $\mathrm{S} 20$ and its flanking regions. Journal of Biological Chemistry 256, 8177-8182.

Matin, A. \& Matin, M. K. (1982). Cellular levels, excretion and synthesis rates of cyclic AMP in Escherichia coli grown in continuous culture. Journal of Bacteriology 149, 801-807. 
MilleR, J. H. (1972). Experiments in Molecular Genetics. Cold Spring Harbor, NY: Cold Spring Harbor Laboratory.

Pardee, A. B., JaCOB, F. \& MONOD, J. (1959). The genetic control and cytoplasmic expression of inducibility in the synthesis of beta-galactosidase of Escherichia coli. Journal of Molecular Biology 1, 165168.

Potter, K., Chalmers-larson, G. \& Yamazaki, H. (1974). Abnormally high rate of cyclic AMP excretion from an Escherichia coli mutant deficient in cyclic AMP receptor protein. Biochemical and Biophysical Research Communications 57, 379-386.

RedDY, P., Peterkofsky, A. \& MCKenNeY, K. (1985). Translational efficiency of the Escherichia coli adenylate cyclase gene: mutating the UUG initiation codon to GUG or AUG results in increased gene expression. Proceedings of the National Academy of Sciences of the United States of America 82, 56565660.

RoY, A. \& Danchin, A. (1982). The cya locus of Escherichia coli $\mathrm{K} 12$ : organization and gene products. Molecular and General Genetics 188, 465-471.

Roy, A., Danchin, A., Joseph, E. \& Ullmann, A. $(1983 a)$. Two functional domains in adenylate cyclase of Escherichia coli. Journal of Molecular Biology 165, 197-202.

Roy, A., Haziza, C. \& DANChIN, A. (1982b). Regulation of adenylate cyclase synthesis in Escherichia coli: nucleotide sequence of the control region. EMBO Journal 2, 791-797.
Stormo, G. D., Schneider, T. D., Gold, L. \& EHRENFEUCHT, A. (1982). Use of the 'Perceptron' algorithm to distinguish translational initiation sites in E. coli. Nucleic Acids Research 10, 2997-3011.

ULLMANN, A. (1984). One-step purification of hybrid proteins which have beta-galactosidase activity. Gene 29, 27-31.

UllmanN, A. \& Danchin, A. (1983). Role of cyclic AMP in bacteria. Advances in Cyclic Nucleotides Research 15, 1-53.

Ullmann, A., Tillier, F. \& Monod, J. (1976). Catabolite modulator factor: a possible mediator of catabolite repression in bacteria. Proceedings of the National Academy of Sciences of the United States of America 73, 3476-3479.

Ullmann, A., Joseph, E. \& Danchin, A. (1979). Cyclic AMP as a modulator of polarity in polycistronic transcriptional units. Proceedings of the National Academy of Sciences of the United States of America 76, 3194-3197.

Wang, J. Y. J., ClegG, D. O. \& Koshland, D. E., JR (1981). Molecular cloning and amplification of the adenylate cyclase gene. Proceedings of the National Academy of Sciences of the United States of America 78, 4684-4688.

Wayne, P. K. \& Rosen, O. M. (1974). Cyclic 3'-5'adenosine monophosphate in Escherichia coli during transient and catabolite repression. Proceedings of the National Academy of Sciences of the United States of America 71, 1436-1440. 